\title{
Introduction: Modern Arab-Islamic Scholarship on Ethics
}

\author{
A Reflective Contextualization
}

Mohammed Hashas and Mutaz al-Khatib

The question whether there are theories in Islamic ethics ${ }^{1}$ does not differ much from the similar question whether there is an Islamic philosophy. This issue was first raised by some 18th and 19th century European Orientalists—à la Johann Jakob Brucker (1696-1770), Wilhelm Gottlieb Tennemann (1761-1819), and Ernest Renan (1823-1892) ('Abd al-Rāziq [1944] 2011, 8) —and has been revisited by a number of ongoing studies, particularly since the modern edition and publication of various manuscripts originally written in the classical period (before the 19th century) by various Muslim and non-Muslim scholars in and from different Islamic contexts - the Arabic, Persian, Ottoman, Indian and Malay contexts - where philosophy did not die out as a discipline, as the claim has gone for some good time (El-Rouayheb and Schmidtke 2017, 1-7). A review of classical Qur'anic exegeses shows that neither the exegets have been concerned with building theories of ethics based on the Qur'an (al-Khațîb 2017), nor have Muslim scholars in general, even though the sacred text is all about ethics (Rahman 1982, 154-155). It was the challenge of modernity that required revisiting the Islamic tradition in search of Islamic philosophy, or Arab(ic) philosophy as some prefer to call it (Ṣalībā 1989, 9-11). The avant-guardist thinkers of the so-called Arab-Islamic nahda (awakening or renaissance) of the 19th century, like Rifa'a Rafi' al-Tahtawi (1801-1873), Jamal al-Din al-Afghani (1838-1897) and Muhammad Abduh (1849-1905), did not deal with this question of ethics as contemporary scholars do. Intead, they focalized the question of reason and rationality at the time. The colonial context did not help them to develop modern theories of ethics, nor to delve into the vast heritage of the tradition to find ethical starting points from where to build and inspire ethical responses to the challenges of modern times. However, new arguments to consider the Qur'an to be a philosophical and ethical text have emerged from the mid-2oth century

1 We refer to ethics in both singular and plural forms, following the Arabic use: khuluq (sing.) and $a k h l \bar{a} q$ (pl.). In Arabic, ethics are often in plural form when the concept and norms are in focus, and in singular form when the "character" of someone is described. We also note that we do not engage here into differentiating between "ethics" and "morality"; "ethics" as used here refer(s) to both internal and external source(s) of ethical conduct. 
onwards (Rashwānī 2017), most particularly in the Arab world. Efforts in this direction in Western scholarship have been meager, as argued Majid Fakhry in 1970, but attempts are being made increasingly (Fakhry [1970] 2004, ix; 'Ațiyya 1990, j-d).

A scrutiny of the literature written in English on Arab(ic)-Islamic philosophy for instance shows how scarce focused scholarship on Islamic ethics has been until recently. Up to this point the literature is dominated by the history of ideas, while more focused studies are still missing. Examples of such a trend are the works of Henry Corbin (1962), Montgomery Watt ([1962] 1985), Seyyed Hossein Nasr (2006), Majid Fakhry ([1970] 2004), Oliver Leaman ([1985] 2004), Hans Daiber (1999; 2007), Mohammad Ali Khalidi (2005), Jon McGinnis and David C. Reisman (2007), Massimo Campanini (2008), Anna-Teresa Tymieniecka and Nazif Muhtaroglu (2010), Roy Jackson (2014), Peter Adamson (2015), Anthony Robert Booth (2017), and Souleymane Bachir Diagne (2018). ${ }^{2}$ The Cambridge Companion to Arabic Philosophy (2006), The Oxford Handbook of Islamic Philosophy (2017), The Routledge Companion to Islamic Philosophy (2016), are not an exception too, though chapters devoted to "ethics and politics" or "ethics and political philosophy" could be found in Routledge and Cambridge Companions, or in Adams's and Booth's work.

This form of dealing with Islamic scholarship in general may have had two main reasons. First, European Orientalist views-à la Renan-dominated the 18th and 19th century scholarship on Arab-Islamic thought. The idea was that Arab-Islamic philosophy was merely a transmission and translation of Greek philosophy. It was examined with "Greek lenses" or modern European perspectives, instead of seeking its originality in sciences not related to Greek thought, logic and ethics in particular, like theology ('ilm al-kalām), jurisprudence theories ( figh and ușül al-figh), and Sufism (tașawwuf). The assumption underlying this type of scholarship is that Arab-Islamic philosophy needs to theorize ethics philosophically first, before or instead of focalizing applied ethics, a topic with which literature in the tradition abounds. This assumption clearly neglects or disregards the fact that Arabs and Muslims had sacred texts to take into consideration, i.e. the Qur'an and the Prophetic sayings, which the Greeks did not have. It is quite obvious that a religious community will look first at its sacred text for ethical teachings and behaviour. This explains why the dominant typology of ethics was derived from the Qur'an and the Sunna first, besides literature and popular teachings of the Arabs themselves and of other cultures (Persian and Indian in particular). Such type of works on tahdhïb al-akhlāq or

2 Oliver Leaman and Massimo Campanini have, however, directed their attention to reading the Qur'an as a philosophical text, and to the issue of morality, as will be referred to later in this introduction. 
tahdhïb al-nufüs [betterment of conduct/ethics, or betterment of souls] can be traced to Ibn al-Muqaffa' (d. c. 139/759), al-Muhāāibī (d. 243/857), al-Jāḥiz (d. 255/868), Ibn Abī al-Dunyā (d. 281/894), al-Ṭabarānī (d. 36o/918), Abū alḤasan al-Māwardī (d. 45o/1058), Ibn Ḥazm al-Andalusī (d. 456/1064), al-Rāghib al-Ișfahānī (d. 422/1108), Ibn al-Jawzī (d. 597/1200), among others. Focus on this dominant typology of ethical literature leaves aside other disciplines which are more systematic in the tradition, like legal theories, philosophical treatises, theological or Sufi arguments. A scrutiny of the vast corpus of literature of these disciplines shows that ethics have always been present, sometimes even at the center, of thought and intellectual production, either as chapters in certain reference works, or as an implicit worldview of Islam and Sharia, without which thought and work ('amal, i.e. practice/praxis) are considered imperfect or inacceptable. It is in this sense that scholars like Toshihiko Izutsu (1966), and Wael B. Hallaq (2013; 2019), among others, consider Sharia ethics as a worldview that characterizes classical Islamic thought, and not understanding it in this way does immeasurable harm to the objectives of Sharia. It is in these disciplines that various approaches of Islamic ethics could be decoded and examined (alṬawil 1952, 256-387; Qābīl 1984, 7-11; 'Ațiyya 199o, j-d).

The second reason why scholarship has neglected to focus on Islamic ethics has to do with historical circumstances and the episteme that influences thought. Ethics has become an important modern discipline of study, growing more and more interdisciplinary in the secularized contexts of Europe. This is not to say that the Arab-Islamic context did not witness debates on ethics in classical periods, based on reason alone, or primarily on reason. The case of the Mu'taziliss is more than convincing to prove that even a religiously dominated context could bring about rational tendencies, and bring forth rational ethicist literary and theological figures like Ibn al-Muqaffac, alMáarrī (d. 449/1058), Abū Bakr b. Zakariyyā al-Rāzī (d. c. 313/925) and Ibn al-Rāwandī (d. c. 298/911) — evidently without stating that other theological tendencies and figures are irrational or less rational. The main argument here is that the importance ethics has gained as an independent and interdisciplinary philosophical field has to do with the modernity paradigm, and with the weakening of the classical dominant religious worldview that used to govern the entire society. While experiencing and debating modernity which challenges the worldview of religion, the Arab-Islamic world too is shedding new light on this vital intellectual and practical discipline of ethics, and is doing so from various angles and tendencies. Below we refer to some prominent examples of scholarship on Islamic ethics in both English and Arabic, without claiming that these references are exhaustive for all the major texts written in these languages, let alone the other languages of Muslim majority contexts, like Persian, 
Turkish, Urdu, and Malay. The examples in Arabic focalize the Egyptian context not only because of its productivity on the topic especially in the first part of the 2oth century, but also because it draws a picture of the diversity of approaches on the question of ethics in the age of encountering modernity and debating ways of reform and renewal. We will also briefly discuss Maghrebi examples subsequently. As to the examples written in English, they are from the 1950s onwards, also a period of intellectual search for ways of reading the sacred text based on ethical concepts.

In this introduction, we refer to two major types of scholarship on ethics in the Islamic tradition: one examines the sacred text of the Quran, and thus belongs to what we could refer to as "Qur'anic ethical system/thought" scholarly tendency, and the other examines "Islamic ethical thought" in the tradition at large, like in legal theory, theology, philosophy, and Sufism, and not limited to the Qur'an. In the English literature we refer to, the works of Daud Rahbar and Salih al-Shamma belong to the first category, while the works of Majid Fakhry, George Hourani, Mariam al-Attar, and Amyn B. Sayoo, to name these among others, belong to the second. General notes on these works will be given below, before a similar distinction is adopted to discuss Arabic literature on the topic, mainly in Egypt in the 2oth century, before reaching the main topic of the studied context and the project of the "trusteeship paradigm."

We start with the Pakistani international scholar Daud Rahbar (1926-2013), who revisits the ethical message of the Qur'an in his PhD dissertation prepared at Cambridge University (1949-1953) and published in 196o. In the work entitled God of Justice: A Study in the Ethical Doctrine of the Qur'an, he argues that justice, God's justice, prevails over His mercy and that the Qur'an's ethical call stems from this cardinal message of justice. It is "God's Strict Justice" that instils in the believer's conscience a sense of fear of being overlooked by God's justice and mercy, instead of fear of God the Capricious Tyrant, as has been classically interpreted to be one of God's Ninety-Nine attributes or God's Beautiful Names (Rahbar 196o, xiii; Rashwānī 2017, 169-170). Rahbar also revisists theological concepts that are dominantly abstract, like the attributes of Essence and Absolute, to emphasise the direct relation between God and man, as a way of bringing to the fore the concept and value of justice that human beings need and cherish (Rahbar 1960, xv). Samir Rashwani refers also to the PhD dissertation of the Iraqi Salih Hadi al-Shamma, prepared at Edinburgh University entitled The Ethical System Underlying the Qur'an: A Study of Certain Negative and Positive Notions (1959); Rashwani says that al-Shamma does not take a clear position in stating whether the Qur'an provides an ethical system or not. Al-Shamma, however, argues that Qur'anic ethics tend to be more practical than theoretical, and they emphasise obligation (akhlāq al-wājib) (Rash- 
wānī 2017, 182-184). Toshihiko Izutsu's Ethico-Religious Concepts in the Qur'an (1966), previously published as The Structure of Ethical Terms in the Koran, in 1959, can be added to this line of scholarship written in English, but its attempt is more cultural-linguistic than theoretical-philosophic, though concepts and their developments do matter in examining the way ethics are presented in a particular worldview. Overall, Izutsu was of the view that "Islamic thought at its Qur'anic stage makes no real distinction between the religious and the ethical" (Izutsu [1966] 2002).

Majid Fakhry, the Lebanese scholar of Arab-Islamic philosophy, published on ethics in both Arabic and English. First, he published al-Fikr al-Akhlāqi alArabi (Arab Ethical Thought) in 1978. The volume is mostly a selection of some major themes, works and figures that deal with ethical issues. He starts by dividing Arab scholarship on ethics into two major types: adab khuluqi (ethical literature) and fikr khuluqi (ethical thought). The first is a collection of ethical and moral teachings from different traditions, as well as personal experiences, and the second is more organized in a systematic and philosophical format. Ibn al-Muqaffa', Abū al-Ḥasan al-'Āmirī (d. 381/992), Abū Sulaymān al-Sijistānī alManțiqi (d. c. 377/100o), Miskawayh (d. 421/1030), for instance, belong to the first category (i.e. ethical literature), while some works and treateses of philosophers and theologians like al-Kindī (d. c. 259/873), al-Fārābī (d. 339/950), Abū Bakr al-Rāzī, al-Qāḍī 'Abd al-Jabbār (d. 415/1025), al-Māwardī, al-Ghazālī (d. 505/1111), Fakhr al-Dīn al-Rāzī (d. 6o6/1210), and Ibn Ḥazm belong to the second (i.e. ethical thought). Then he provides excerpts from the works of these scholars as they relate to different ethical issues, like justice, good and evil, human behaviour and judgement (Fakhry [1978] 1986, 9-10). Later on in 1991 Fakhry published Ethical Theories in Islam in English. Here, he introduces a different and clearer typology of ethics, which he puts in the following order:

1) Scriptural ethics, in which Quranic ethos is underlined.

2) Theological ethics, in which ethical rationalism and ethical voluntarism theories are discussed, with reference to the Ash'arīs and Mu'tazilīs.

3) Philosophical ethics, with reference mainly to the works of philosophers from Aristotle to al-Kindī, al-Rāzī, al-Fārābī, Ibn Sīnā (d. 428/1037), Ibn Rushd (d. 595/1198), Yahya Ibn 'Adī (d. 363/974), Miskawayh, Nașīr al-Dīn al-Ṭūsī (d. 672/1273), and Jalāl al-Dīn al-Dawānī (d. go8/1502).

4) Religious ethics, which he studies with reference to Ibn Abī al-Dunyā (d. 281/894), Abū al-Ḥasan al-Māwardī, Ibn Ḥazm, al-Rāghib al-Iṣfahānī, Fakhr al-Dīn al-Rāzī, and al-Ghazālì (Fakhry 1991).

A more synthetical work on Islamic ethics is found in the collected articles of George Hourani, published in 1985 as Reason and Tradition in Islamic Ethics. Unlike the common traditional presentation of ethics in the tradition, which 
often summarizes either certain major works or the ideas of certain influential figures, Hourani synthesizes Islamic ethical theories into four trends, close to Fakhry's typology, but with reference to two lines of argumentation: ontology and epistemology, i.e. the nature of ethical values, and how humans can know them in particular contexts, respectively. More importantly, Hourani focuses on what he considers the original contribution of the tradition regarding ethics, that is, in jurisprudence debates on the sources of law and in theology (kaläm). He considers the latter philosophical in methodology when it comes to dealing with ethics (Hourani 1985, 19). It took a few more years for some other interesting works on Islamic ethics to appear in English.

Mariam al-Attar's Islamic Ethics (2010) also presents Islamic theories of ethics differently, synthetically. After treating Qur'anic-hadith ethics, pre-Mu'tazilī and Ash'arī ethics, she focalises the later Mu'tazilī ethical theory of al-Qâdị 'Abd al-Jabbār, whose twenty volumes work al-Mughnī was found in the 1950s in Yemen. Al-Attar, through her lenghty presentation of rational ethical theories, argues that there is no clear evidence that "divine command theory" is what prevails in Islamic thought (Al-Attar 2010, 142), an argument many scholars may not agree with. Amyn B. Sayoo's edited volume A Companion to Muslim Ethics (2010) takes a more modern approach in tackling the topic, by examining applied ethics for concrete challenges, like ecology, art, economy, dispute resolution, tolerance, and nonviolence. Sayoo's edited volume appears as an exploration of an earlier work of his own, Muslim Ethics: Emerging Vistas (2004), in which he makes classical ethics, themes and figures talk synthetically to modern secular challenges.

Besides these recent works, a collective project on this under-researched subject has been inaugurated by the birth of the Journal of Islamic Ethics, launched by the Research Center for Islamic Legislation and Ethics in Doha, Qatar, in July 2017, and it dedicated its first issue to the theme of the Quran and Ethics; the subtitle of the introductory chapter reflects the point: "A Pressing Demand and a Promising Field" (Ghaly 2017, 1-5); a book series Studies in Islamic Ethics, and an MA programme in Applied Islamic Ethics have been launched by the same Center as well.

As to modern literature in Arabic on ethics, it cannot be exhausted, nor can it be thoroughly reviewed or sketched out here. Ahmad Abdalhalim 'Atiyya has accomplished this task in his rich text Al-Akhlāq fíal-Fikr al-Arabì al-Mu'ạsirir (Ethics in Contemporary Arab Thought, 199o). 'Atiyya outlines three major scholarly trends that work on ethics in the Arab world:

1) The first annotates, revises, edits, and publishes classical works and manuscripts on Islamic ethics as well as their relation to Greek ethical thought. 
2) The second translates and engages with modern European thought on ethics.

3) The third, which is still emerging according to him, tries to build Arab ethical thought that responds to modern challenges in society and life innovatively ('Ațiyya 199o, ha-kh).

Because our interest in this limited space is to contextualize, and not fully analyze, the debate on Islamic ethics, we will adopt the "Qur'anic ethical system/thought" and the "Islamic ethical thought" typology used above and examine some relevant texts mostly from the Egyptian context, before discussing the Maghrebi context, since it is the context in which "trusteeship ethics" and the "trusteeship paradigm" have emerged.

For the Egyptian context, Abdullah Draz's work is the most representative of the first type of "Quranic ethical thought," and the other works could fall, broadly, in the second category of "Islamic ethical thought," in which we can discern two leading figures: Ahmed Lutfi El-Sayed (1871-1963) and Mustafa Abd al-Raziq (1885-1947). These two figures, in turn, represent two major scholarly trends: one that builds on the Graeco-Arab philosophical tradition, in the light of modern European philosophical schools, and espouses the separation of religion from revelation to form an independent discipline of ethics in the tradition. The other trend takes particular sciences of the classical tradition as the starting point to speak of original sources of Islamic ethical theories that could nurture modern explorations in the field (see Al-Khațîb 2019).

In the first modern Arabic translation of Aristotles' (d. 323 BCE) Nichomachean Ethics of $1919^{3}$ —based on the French edition of Jules BarthélemySaint-Hilaire (1805-1895) —, Ahmed Lutfi El-Sayed ${ }^{4}$ says that, in order to rehabilitate Arab and Egyptian philosophy, Arab scholars have to study Aristotles' philosophy again (Lutfi El-Sayed [1919] 1934). Lutfi El-Sayed was inclined towards utilitarian ethics, as championed by the British philosophers Jeremy Bentham (1748-1832) and John Stuart Mill (1806-1873). He influenced a generation of students and scholars interested in the French and European philosophical model in general, before another generation interested in Arab-Islamic philsophy grew up in the 1940s (al-Khatib 2019, 164-169). This interest in philosophy could also be deduced from the widespread reception of philosophical textbooks at the university as well as high school levels. For instance, the lectures of reputed European scholars teaching at the University of Egypt were published as we will see subsequently, next to texts written by local scholars.

3 First translated from Greek into Arabic by Ishāa Ibn Hụnayn (d. 298/910).

4 The first president of Cairo University, which was founded in 1908. 
Amin Wasif Bek (1867-1928) published his lectures at the Egyptian University in five short books on major disciplines of philosophy (psychology, aesthetics, logic, ethics, and metaphysics) as Usūul al-Falsafa (The Fundamentals of Philosophy) in 1921. He dedicated to ethics the fourth booklet, in which he uses neither references, nor any religious citations (Wāṣif Bik 1921). Apparently, it is the scholastic work of Ahmad Amin (1886-1954) Kitāb al-Akhlāq (The Book of Ethics), published in 1929, that had circulated more widely. It was adopted by the ministry of education for high schools in Egypt, and had a more lasting impact, according to Ahmad Abdelhalim 'Atiyya (Amīn [1929] 2011; 'Ațiyya 1990, d). The book deals with topics like conscience (damir), ethical judgement, good and evil, the individual and society, rights and duties, the meaning of obligation, the ethical model, and virtue, which is the last chapter-whereas classical Arab-Islamic texts would commence with the theme of virtue. Amin says that human beings can depend on their intuition to find out what is good and what is evil, and that education, family, and religion only help in that process. Intuition is what makes human values shared and universal (Amīn 2011, $32,43)$. His three pioneering volumes in modern Arabic scholarship on Islamic civilization (Fajr al-Islām, 1929; Ḍ Dụa al-Islām, 1933; Zuhr al-Islām, 1945) refer to ethics when speaking about Islamic theology and philosophers, and dedicates chapter six of the third volume to the topic. In this chapter he writes that there are generally two kinds of ethical scholarship in the Islamic tradition: one based on the Qur'an, the Sunna, wisdom teachings and moral stories, and the other developed later, when the tradition came in touch with Greek philosophy. At this point, ethics became more systematic and rationalized in categories and concepts. Ibn al-Muqaffa' and al-Māwardī's works on ethics, for example, belong to the first category, while Miskawayh, Abū Bakr al-Rāzī, and Ikhwān al-Ṣafā's belong to the second. Al-Ghazâlī is put in between the two categories (Amīn [1945] 2013, 389-400). A similar division is adopted by Majid Fakhry in Arab Ethical Thought as seen above ([1978] 1986, 9-10).

Up to this point scholars link the study of Arab-Islamic philosophy to Greek philosophy, without distinguishing certain Islamic disciplines as distinctively and-or originally philosophical too. Mohammed Abed al-Jabri (1936-2010) known for his Naqd al-'Aqlal-'Arabì (Critique of Arab Reason) in four volumes, names, in passing but with a clear recognition, two modern scholars as the engines behind the rebirth of the study of Arab-Islamic philosophy after centuries of cultural and philosophical decadence. In his history of ideas, this era started after the last most important philosopher, the Andalusian Ibn Rushd/ Averroes. Al-Jabri names the Egyptians Mustafa Abd al-Raziq and Ibrahim Madkour (1902-1996) as the two scholar-thinkers that have genuinely replied to what he calls "philosophical Orientalism," a tendency led by a number of 
Eurocentrist scholars of the 18th and 19th centuries (al-Jābrī 1991, 63-64). We will make a few notes on each of their most important works that are relevant to the topic of ethics.

It is with Mustafa Abd al-Raziq that the study of ethics in Arab-Islamic philosophy takes a new turn. He was a Sheikh trained at al-Azhar, subsequently obtained his PhD at the Sorbonne University in Paris, where he studied under scholars like Émile Durkheim (1858-1917), and then taught Islamic jurisprudence in Lyon. He became Rector of al-Azhar, and was appointed minister of Religious Affairs and Endowments eight times, to be the first Azhari to hold such a position. He is one of the direct students of the famous reformist scholar Muhammad Abduh (1849-1905). Mustafa Abd al-Raziq started teaching what came to be known in the curriculum as "Islamic philosophy," along with Emile Bréhier (1876-1952) and André Laland (1867-1963), at the Faculty of Arts of the Egyptian University (later on named King Farouk University and now Cairo University), where Taha Hussein (1889-1973) was the only other Egyptian professor. Before that, "Islamic philosophy" as a subject was part of philosophy or general philosophy course, and it was taught from a "foreign" perspective, and often without underscoring its original aspects, by European scholars of the Islamic Orient who were teaching philosophy at the university, like the Italians Davide Santillana (1855-1931), Carlo Alfonso Nallino (1872-1938), the English Thomas Walker Arnold (1864-1930), the French Louis Massignon (1883-1962) (in 'Abd al-Rāziq 2011, 45, n. 2), and the Spanish Comte de Galarza (1878-1938) (Reid 1987; 'Atiyya in De Galarza 1920, 3-4). In Tamhìd li-Tärīkh alFalsafa al-Islämiyya (Introduction to the History of Islamic Philosophy, 1944), Abd al-Raziq's argument for "Islamic philosophy" and where to find its originality would influence some prominent new students and later on professors of Islamic philosophy, like Ali Sami al-Nashar (1917-1980), and in turn his student Ahmed Mahmoud Subhi, and the latter's students, like Abdelhay Qabil, who also published on Islamic ethics (Qabil 1984, 5).

In his three volumes Nash'at al-Fikr al-Falsafífí al-Istäm (The Development of Philosophical Thought in Islam, published in 1966, 1968, 1969, respectively) Sami al-Nashar defends the originality of Islamic philosophy in its theology, jurisprudence theories and Sufism (Al-Nashar [1966] 1977, 1:18). His student Ahmed Mahmoud Subhi continues this line of thought in Al-Falsafa al-Akhlāqiyya fì al-Fikr al-Islāmī (Philosophy of Ethics in Islamic Thought, 1969) in which he presents the Mu'tazilis and the Sufis as two opposing trends- the first rational-abstract oriented, and the second work/practice oriented - that both advanced original theories of ethics. He puts Ikhwān al-Ṣafā and Miskawayh forward as two major examples of schools that theorized ethics in a conciliatory way, neither purely rational nor purely traditional/metaphysicist 
(Subhi [1969] 2006). Both scholars see that Islamic philosophy is different and originally spiritual in orientation, and that it does not need to be Aristotelian, metaphysics-free by default (Subhi 2006, 19-20).

As to Ibrahim Madkour, he too is an Azhari graduate who earned his $\mathrm{PhD}$ in philosophy from Paris University in 1934, where he studied under Massignon. He succeeded Taha Hussein after his death as the diretor of the Cairo Arab Language Assembly. He revised, edited and wrote on various manuscripts of Muslim philosophers, and influenced a generation of young scholars of ArabIslamic philosophy; his most known work is Fī al-Falsafa al-Islämiyya: Manhaj wa-Tațiquh (On Islamic Philosophy: A Method and Its Application, in two volumes, 1947). Even though the table of contents of this work does not use the word ethics in its chapter headings, it is still not absent from the way he presents his reading of the tradition. The first volume studies Islamic philosophy based on three major theories or concepts: (1) happiness, (2) prophetology, and (3) the soul and its eternity. The second volume centralizes two concepts: (1) divinity, and (2) free will. Synthetically, in all of these concepts the idea of ethics does not seem central, but it is present and permeates different scholarly disciplines and their concepts.

Madkour argues that Islamic theology, led by Mu'tazilī figures like Abū alHudayl al-'Allāf (d. c. 227/840) and Ibrāhīm al-Nazzāām (d. c. 230/835), was a philosophy based on a religion that nurtured it, before opening up to alKindī, often considered to be the first Arab-Muslim philsopher. According to Madkour, Islamic philosophy was born in and by virtue of religion, first and foremost thanks to debating the notion of tawhìd (Oneness of God) (Madkour, [1947] 2015, 2:277-278). This argument goes along with the argument of Henry Corbin (1903-1978) who says that philosophy in the Islamic context is "essentially linked to the religious and spiritual fact of Islam," which he sometimes calls "prophetic philosophy" (Corbin 1962, xiv-xv).

A similar way of approaching ethics as a discipline of study in modern Arab scholarship is to be found in the work of Muhammad Yusuf Musa (1899-1963), an Azhari scholar and one of the students of Louis Massignon and Mustafa Abd al-Raziq, referred to above. In his first work History of Ethics ([1940] 1953, 190), he approaches the theme in a scholarly manner, and does not make Islamic ethics a unique topic of focus, as it is treated along with ethics in other traditions (the ancient Orient, the Egyptian, the Greek, Jewish, Christian, Islamic, and European). His other shorter work Issues in the Philosophy of Ethics (1940) centralizes both the topic and the way it is studied philosophically, and grants Muslim philosophers a voice along with their European counterparts. His more important work, clearly a more mature one, goes further and opens new pathways for researching not only ethics but Islamic philosophy at large, based on 
its fundamental book, the Qur'an. The book is entitled The Qur'an and Philosophy (1958) and can be considered to be a pioneering text on this topic. There are only a few works that recently have started to explore this subject in English, like Oliver Leaman's The Qur'an: A Philosophical Guide, and Islam and Morality (2016; 2019), and Massimo Campanini's Philosophical Perspectives on Modern Qur'anic Exegesis (2016). Earlier in 1947, Abbas Mahmud al-'Aqad (1889-1962) wrote Qur'anic Philosophy, a general text that does not reflect the expected profundity of the title, to demonstrate that not only does the Qur'an not contradict reason, but it is also a book that contains concepts that are treated philosophically, and is thus open to being a text rich of philosophical calls; ethics is among these concepts, imbued with divine attributes as their guidance for human excellence, perfection and aesthetics (Al-'Aqqād [1947] 2013, 23-31).

This period of Egyptian scholarly discussions on ethics gives birth to an important attempt of reading the Qur'an using ethical concepts. It is the work of the Azhari scholar Muhammad Abdallah Draz (1894-1958). ${ }^{5}$ Draz spent twelve years studying in France preparing his magnum opus La Morale du Koran, which was originally his $\mathrm{PhD}$ dissertation at the Sorbonne University, which he defended in 1947, and published in $195^{\circ}$ in French. Its Arabic version appeared some 13 years later, at the initiative of Abdessabur Shahin (19292010), another Azhari scholar. The English translation appeared only much later, in 2008. Draz divides his book into a theoretical and practical part of ethics. In the first he studies the concepts of obligation, responsibility, sanction, intention and inclinations and effort in the Qur'an, and refers to ancient and modern theories of ethics in this regard. In the second part he examines personal ethics, as well as family, society, state, and religious ethics and the way the Qur'an speaks about them in a coherent form, unlike the way Qur'anic ethics have been presented in separately-quoted verses and teachings, a gap in scholarship for which he blames both Muslim and non-Muslim scholars (Darrāz 1973; Draz 2008; see also Rashwānī 2017, 159-169).

This diversity in approaching Arab-Islamic ethics demonstrates that the issue is fundamental both in scholarly circles as well as in political circles where fierce debates are being waged on the question of what kind of ethics should prevail in the public sphere, should they be religious, secular, secular-religious, fully rational, or semi-rational? How can changing societies, as in the Arab world, look back at their ethical tradition to form a more fitting interpretation to cope with the challenges of the secular-modern world?

5 Around this period of time, Draz's compatriot the famous Abdurrahman Badawi (1917-2002) was probing the question of ethics from an existential perspective (Badawi 1953). 
The intense interest in the study and revival of Arab philosophical scholarship on ethics of the 1930s and 1940s, up to the 196os, as briefly reviewed above, faded in the 1970s and 1980s mostly because of the phenomenon of Islamic awakening and the rise of political Islam. For Instance, the "global mufti" Yusuf al-Qaradawi (b. 1926) wrote Al-Qiyam wa-l-Akhlāq fì al-Iqtișād al-Islāmì (Values and Ethics in Islamic Economics, 1995) and recently he published Akhlāq al-Isläm (The Ethics of Islam, 2017), in the introduction of which he identifies ethics as the core message of Islam, and faith without applied ethics as null and void. While he certainly tackles various themes, he does not conceptualize or theorize. He rather studies how applied ethics are fundamental to the tradition, and supports his argumentation with Qur'anic verses and hadith. In this way we can put al-Qaradawi's first work on economics in the "Islamic ethical thought" category and his second one in the "Quranic ethical thought" category, to use our generic typology proposed earlier, or "Scriptural ethics" in Fakhry's typology.

Returning to "Islamic ethical thought" in the context of the Maghreb, Mohammed Arkoun (1928-2010) tried to apply socio-linguistic and historicist approaches not only to the entire tradition and what he centralized and called "Islamic reason" but most particularly to what he called "Qur'anic ethicality" (al-akhlāqiyya al-Qurāaniyya) (Arkūn 199o, 21-44). However, Arkoun did so as a "historian of ideas," from "critical perspectives" as a scholar (Arkūn 1990, 22), to present the classical Islamic ethics in its past time so as to re-interpret it in the light of modern historical challenges, and he did not aim at theorizing ethics as a theologian-philosopher. His deconstructivist approach of reading the tradition did not aim at theorizing an ethical theory to renew Islamic thought, but to open it up to the "unthought in Islamic thought", in his words; his "spiritual responsibility" was more a pure individual source of moral conduct than of generally applied ethics; he says, "I am introducing the concept of spiritual responsibility not to reactivate the idealistic claims for religious spiritualism but to problematize the current reference made to the 'dignity of man'" (Arkoun 2007, 284).

To refer to another prominent Arab thinker and the place of ethics in his scholarship, the case of Mohammed Abed al-Jabri and his al-'Aql al-AkhlāqìalArabi (Arab Ethical Reason, 2001), the fourth volume of his quadrilogy Critique of Arab Reason, is of paramount relevance. Especially since he and Taha Abderrahmane (b. 1944) did not go along well, and took different scholarly paths at the Mohammed $v$ University in Rabat where they both taught in the same department of philosophy for about four decades (See the chapter of Hashas in this volume for more). Al-Jabri was driven by the idea of political change in the Arab world, and on his reading of the tradition a lot of ink has been 
spilled, either for or against, since he introduced new categories for reading Islamic intellectual history, from his first volumes on the "formation" and "structure" of Arab reason, passing by Arab "political" reason, to Arab "ethical" reason (Eyadat, Corrao and Hashas 2018).

Being an optimist Khaldunist in approaching history and its cyclicity, and Averroest in differentiating between the religious sphere and the philosophical one, al-Jabri broadly argues that rhetorical (bayānī) and gnostic ('irfānī) thinking dominated Arab thought, and weakened the flourishing of argumentativerational (burhānì) thought à la Averroes (Ibn Rushd). Specifically on ethics and acknowledging the lack of theorizing in the discipline, he speaks of five major sources of influence on the formation of Arab ethical reason. These are as follows:

1) The Greek influence, which emphasizes the quest for happiness that some major Arab-Muslim philosophers-theologians integrated in their works on ethics.

2) The Persian influence, which emphacizes submission to the king or sovereign as the guardian of the faith, which al-Jabri thinks has had immense impact on Arab political-ethical thought since its fromation.

3) The Sufi and Gnostic influence, heavily borrowed from the Persian mystic and gnostic tradition, which teaches focus on the other-world and disinterest in this-world.

4) The Arab influence, which emphacizes magnanimity (al-murüa).

5) The Islamic influence, which centralizes the value of public good, and which, according to al-Jabri, has been ignored in political thought and ethical practice in Arab-Muslim politics (Al-Jābrī 2001).

Unlike some of the previously mentioned scholars who underscore the originality of Islamic thought in its theories on the sources of law, theological theories of ethics and Sufism, like Mustafa Abd al-Raziq and Ibrahim Madkour whom al-Jabri praises for their important scholarship, he critiques certain legal methods like the use of qiyās (analogy), which he blames for having distanced fiqh from the fundamental sources of law, i.e. the Qur'an and the Sunna, and having gradually neglected maqāṣid al-sharîa (objectives of the Sharia). Most relevant to our discussion here is that al-Jabri states that the Islamic influence that calls for the public good and for social justice has been minor on Arab politics. Moreover, al-Jabri is very critical of gnosticism and Sufism, and their champions Ibn Sīnā and al-Ghazālī, respectively. According to him, Sufism encourages believers to withdraw from worldly affairs. Al-Jabri is also critical of the theologians, because a lot of their approaches, especially those that relate to sovereignty, free will and society, were politically driven, and not purely intellectually motivated. This applies to the Umayyads and their use of determin- 
ism against free will theologies to legitimize their authority, and to scholars like Abū al-Ḥasan al-Āmirī and his friend Miskawayh who both tried to build an interpretation of happiness that is both Islamic and Platonic-Aristotelian, an eclecticism that al-Jabri condems. More importantly, al-Jabri contends that Persian gnosticism as well as Persian literature on obedience to the king, configured as God, were very present in the ethical writings of the two scholars mentioned above. This endangered the scholarly study of ethics and impacted its importation to the Arab-Islamic tradition, he says (al-Jābrī 2001, 393-420). This differs drastically from the positive views two other modern Arab scholars have of Miskawayh in particular, i.e. Costantin Zureiq (1909-2000) and Mohammed Arkoun. The former annotated and edited Tahdhīb al-Akhlāq in Arabic in 1966 and the latter translated it into French in 1969 (Arkoun [1969] 2010). Al-Jabri's representation of the ethical system of Arab thought was not well received by a number of scholars, especially that Islamic ethics of conduct as well as Suf teachings were not centralized in this schematic representation of al-Jabri (al-Bishrī 2004). Taha Abderrahmane wrote a long methodological text to reply to the overall Jabirist project of reading the tradition, and criticized him for being reductionist and selective, and not comprehensive in his approach ('Abd al-Raḥmān 1994).

\section{Ethics in the Trusteeship Paradigm of Taha Abderrahmane}

Having broadly sketched out the place of ethics in modern Arab-Islamic scholarship, we can say that it has gradually moved to the central stage of scholarly debates, after the political debates of how to govern and what political system to implement were the first major scholarly concern. Even if the question is about political reforms - whether to adopt a secular, civil, religious, or secularreligious system - ethics come into play, since it is indicative of both fidelity to the tradition, and fidelity to the aspirations of people for a better future. It is in this context that a major philosopher emerges on the scene: the Moroccan Taha Abderrahmane, whom this volume aims to shed light on, since he is still under-researched especially in the English-speaking scholarly community. ${ }^{6}$

Taha Abderrahmane became aware of the need of philosophy in the Arab world after the Six-Day War of 1967. After studying logic and the philosophy of language profoundly, he moved on to engage with especially modern "Western" philosophy, and to theorize commonly debated and discussed concepts

6 His detailed biographical and intellectual sketch is left to the first Chapter of Part One of this volume. 
from a paradigm of thought he has been developing since the late 1970s and early 1980s. This paradigm recently has become known as the "trusteeship paradigm," and "trusteeship critique" (Hashas 2015, 2019). At the heart of this paradigm lies the question of ethics. As a pious scholar who belongs to a Sufi order for his spiritual enrichment, Abderrahmane argues that the core of the Islamic message is ethics, and it is around ethics that he builds his project, the trusteeship paradigm. Based on this core message, we outline four of his major arguments that we consider to be original and profound, leaving aside the limitations of his project for now.

First, Abderrahmane has set his aims high. He aspires to reground ArabIslamic philosophy on the distinctive feature of ethics. At this level, he directs double layered critique at most classical philosophers that he considers to be imitators of Greek philosophy. For him Ibn Rushd is but an imitator of Aristotle, since the latter did not try to go beyond the Greek Aristotelean tradition. Abderrahmane is closer to al-Ghazālī, not only because of their Sufi fusion of reason and religion, but also because the latter profoundly engaged with Greek philosophy albeit indirectly, since he lacked command of Greek. Abderrahmane argues that most classical Muslim philosophers granted reason the same place Greek philosophy did and tried to reconcile reason with revelation, whereas they hardly tried to build a paradigm based on their new religion, Islam and its worldview. He argues, however, that it is in ușül al-figh (Islamic legal theory) and philosophical Sufism that one finds the importance of ethics underscored, which finds its origin in the Qur'an and the Prophetic Sunna. Abderrahmane directs a similar critique at almost all contemporary Arab and Muslim thinkers and philosophers, with the exception of a few figures like Muhammad Iqbal (1877-1938) and Fazlur Rahman (1919-1988) to whom he shows more scholarly respect. The others have fallen into the modern trap of dichotomous thought of reason versus revelation, reason versus religion, religion versus politics, which is a European import, according to him. From here he launches his major (third) critique to "Western modernity," which he considers domineering, hegemonic and utilitarian to the core. It has stolen from man his liberty to be free, and this has been instilled through the idea of pure reason as the ultimate reason. For Abderrahamane, reason is only a means to other more ethical ends in life, and the human rational faculty consumes itself if it does not have a transcendental element in it for guidance. Hence the importance of revelation in his paradigm and Islamic revelation in particular, since it is comprehensive and embraces the other revealed traditions. Abderrahmane challenges the foundations of philosophical thought in various volumes, and concludes his project with the ideas we phrase as such: human beings are ethical beings. They either can be ethical or not. Humanity is defined 
by this ethical identity, and not by its rational faculty. The more ethical humanity is the more human it is, and the less ethical it is the less human it is. This is how he sees the way to fix the predicament of Western modernity. He rejects its current Western achievements and proposes going back to its "essence" or "spirit" to correct it. Ethics must be its essence, not reason. He states that the sublime Sufi worlds of aesthetics and elevation have opened his heart to the other possible worlds he envisages. He engages with modern and contemporary philosophers in his various works as no other modern Arab scholar has done. Put differently, originality in Arab philosophy based on Islamic ethics can be found through these other ways of seeing and doing. If reason remains the means and the end, then only mimetic ideas would emerge, since this is already realized in the modernity of the "West." Multiple modernities are possible. A philosophy that does not differ is not philosphy, he argues. With this argument, he is not Ghazalian. He wishes that the Arabs, and Muslims at large, start developing their own rational philosophy, which will be able to engage with the world and contribute to it.

Second, Abderrahmane is well versed in both classical Islamic scholarship and its various disciplines, particularly philosophy, theology, Sufism, Islamic legal theory (ușül al-figh), and in modern Western philosophy. His scholarly command of major languages of philosophy (Greek, Arabic, German, French, and English) has allowed him direct access to the sources, though his bibliographies are often in Arabic, French, and English only. His mastery and use of the Arabic language appears to be unique and genuine to the extent that his works are full of newly coined terms and concepts—causing confusion and sometimes also repetition of the same meaning in different ways. He always cites Qur'anic verses as epigraphs of his books, and also in the footnotes, but never in the body of the text, as if to convey that his philosophy is Qur'anic in spirit and background, without making it a form of intellectual proselytism as some intellectual preachers and activists do. Of the modern Arab scholars of Euro-American philosophy he is the most critical, since he does not stop at it, but engages with it critically by trying to find "ethical" or "biased" loopholes in every philosophical project he studies. He has grappled with major philosophers of modernity. He has given hardly any space to modern Arab intellectuals and philosophers, apart from notes in footnotes, and apart from his major critique of two big Arab intellectual figures-i.e. al-Jabri and Abdellah Laroui (b. 1933) — whom he hardly mentions by name though scholars familiar with their projects know he is referring to them. Overall, whether one agrees with his project and argumentation, fully or partly, one cannot deny the profundity and originality of his writing. It would be wrong to call him the "neo-Ghazāli”" because of his particularly strong defence of the practice and tradition of philosophy. 
Most importantly, one has to bear in mind that he wishes to build a genuine Arab philosophical tradition based on its élan of ethics and its language, Arabic, which he has revived and empowered philosophically, as no other Arab philosopher and intellectual scholar has done in modern times. Abderrahmane aims to build an Islamic philosophy of religion, which requires a revival of the spirit of religion, as well as a renewal of its understanding in the modern context, whereas al-Ghazâlī aimed at reviving religion per se. In other words, Abderrahmane is Ghazalian, but in his own way. He is more a philosopher than a theologian, though drawing a sharp line between the two may be too much of a venture.

Third, Abderrahmane is not a Sufi dervish who contents himself with popular rituals and supplications. He wants to go beyond that to find new fertile grounds for philosophy, based on spiritual enrichment and expansion. Besides the transcendental aspect in being a Sufi philosopher, Abderrahmane emphasises the question of practice ('amal), and praxis at large. For him theoretical ethics are null and void. It is what human beings do with their ethical discourse that matters, and not what they say about it. It is only in this way that change can occur. His Sufism is then traditional, but also heavily modern and philosophical. It is not a void spirituality based on belief without action. Abderrahmane is a Sufi philosopher; he philosophizes through Sufism, through his religious background, and he is free to do that. To say that he is too religious, thus his philosophy is not philosophy but theology in the classical Islamic sense of kaläm, does not encompass his overall project and its scope and ambitions. This is not to say that the label theologian-mutakallim is irrelevant. He is a theologian as well, for example when he discusses the utility of the attributes of God to the enrichment of his trusteeship paradigm and the ethics of the individual, or when he proposes an innovative reading of the Qur'an. Still, he does that through an engagement with "modern" secular philosophy, its concepts and themes. The boundaries between the two remain a field of academic discussion when it comes to Arab philosophy, philosophy in Islamic contexts, or "Islamic philosophy" as it is also called.

Fourth, having said this, it is now opportune to stress another major point of possible contention in Abderrahmane's trusteeship paradigm and the Islamic theory of ethics at its base. Abderrahmane aims to renew Arab philosophy and Islamic thinking, and in doing so to reform Arab-Islamic societies in crisis. With this aim, he clashes with "mimetic" intellectual projects, as noted above, but also with political Islam and Islamist movements, which he criticizes harshly in both Sunni and Shi'a contexts. It is then difficult to say that he is "Islamist" in thinking, but certainly he is "Islamic," in the sense that he strongly clings to the sacred text and its spiritual teachings, and their legal interpretations in past 
contexts. His critique of political Islam's search for political power is abundant. It is also difficult to say that he is "secular" or "liberal" as commonly understood, since he is critical of both. Still, he is modern and modernist. Intellectually, he navigates between the traditional and the modern, without accepting modernity at face value, unless reformed. The spiritual ethos he puts on the table as a condition for any reform is hard to meet by the masses and the majority of intellectuals as well as political stakeholders, which makes his project appear either "utopic" or "individual-centered" and not "society-centered." However, it is raising the level of intellectual and spiritual energies of both the individual and society that he aims at to create a better world for Muslims and non-Muslims alike. In his project change starts in the heart and mind, in theory but especially in practice. That is his call for reforming modernity. Without this change from within he does not see other ways of overcoming the current predicament of modernity, and of Arab-Islamic societies in particular.

This volume is divided into two parts, one on theoretical ethics and the other on applied ethics, though in some chapters theory and practice intertwine. The first part is composed of seven chapters that trace the intellectual development of the trusteeship paradigm, and how it relates to issues in legal theory, Qur'anic hermeneutics, political authority, and Sufism. This part is largely comparative. It compares the ethical approaches and theories of prominent scholars, theologians and philosophers, with the theory and philosopher under examination. The second part comprises six chapters and applies this paradigm to issues in the social sciences (sociology and anthropology), medical science, communication theories, global ethics and dialogue. This part too compares the trusteeship assertions on the topic in focus with other prominent theories in the field. Next to the chapters in English seven chapters are written in the Arabic language. These have not been translated to ensure direct access. The book is organized thematically, and not linguistically, that is why the two parts contain chapters in the two languages.

In the first chapter of the first part, "The Trusteeship Paradigm: The Formation and Reception of a Philosophy," Mohammed Hashas synthesises the major intellectual stages that trusteeship has gone through from the late 197os until now. The chapter contextualizes trusteeship as a project different from the ones that developed post-1967. It outlines five major themes that Taha Abderrahmane delved into before giving a clearer shape to his modern theory of ethics as the core of the overall project of the trusteeship paradigm, which are: 
1) Logic

2) Philosophy of language

3) Assessing the tradition

4) Spiritual modernity and moral philosophy

5) Political theology and political philosophy.

After giving an account of the way the project was received mostly in the English and Arabic scholarly community - it met with staunch criticism from some and received admiration from others-the chapter ends with three points related to language and renewal, Sufism and ethics, as a way of reflecting on the scope and limitations of the paradigm examined.

In the second chapter, "Taha Abderrahmane and Abū Isḥāq al-Shāṭibī: Comparative Reflections on Legal Thought and Ethics," Eva Kepplinger conducts a comparative study between the medievalist religious scholar Abū Ishāa alShāțibì (d. 79o/1388) and his theory of maqāsid al-sharīa and Abderrahmane's itimāniyya paradigm. Kepplinger's chapter relates to the current discussions among Muslim scholars over the higher objectives of Sharia, and how to interpret them in modern contexts. What comes first, whether law or ethics, or how they are linked, and what the role and function of human reason is according to the divine, and how Abderrahmane in particular differentiates between law ( figh) and ethics is what this chapter discusses. In so doing, the author, for example, shows how Abderrahmane is critical of the classical order of values that Muslim jurists followed (i.e. preserving religion, life, reason, progeny and property). He is also critical of the classical division of the maqassid in darūriyyāt (obligatory/necessary), hājjïyyāt (vital) and tahsinniyyāt (additional/aesthetic). Ethics was put in the category of tahsiniyyät, while he considers ethics to be the core of any legal thought that goes beyond everything. He adopts a new division: "spiritual values" (qiyam rühiyya), and "life-values" (qiyam hayawiyya). This allows him to navigate between the various subdivisions he develops, as a form of making figh (law) follow ethics, and not vice versa.

In the third chapter "Su'āl al-Akhlāq bayna al-Dīn wa-l-Aql al-Mujarrad: 'Alī 'Izzat Bīgūvītsh wa-Tāha 'Abd al-Raḥmān Namūdhajan" (Alija Izetbegović and Taha Abderrahmane: The Question of Ethics, and Critique of Western Modernity) Mostafa Amakdouf brings two already close philosophers closer. It is known that Abderrahmane shows special respect to both Muhammad Iqbal and Alija Izetbegović (1925-2003). As it claims in the introduction, this comparative chapter is a contribution to linking Islamic philosophical projects that are modern but also critical of Western modernity as well as of mimetic modernity in Muslim majority societies, to form a creative Islamic reply to the modern. Amakdouf outlines these similarities in six points: (1) meaning, (2) ethicality 
(or the essense of ethics) between religion and abstract reason, (3) the formation of ethics and the limitations of abstract reason, (4) ethics between fitra, or natural disposition, and religion, (5) modernist ethics and the incoherence of abstract reason, (6) the need for divine ethics. The idea presented here, according to the studied philosophers, is that human reason is a means to an ethical life, and is not an end in itself, and that rational ethics consists of at least three levels, the most infinite in creativity is supported ethics, which is divinelylinked and divinely-inspired.

In the fourth chapter, "al-I'tirāf fī al-Majāl al-Āmm: Naqd I'timānī li-Mafhūm Fūkū 'al-I'tirāf wa-l-Sulța'” (Confession in the Public Sphere: Trusteeship Critique of Foucault's "Confession and Power") Issam Eido takes us to issues related to the public sphere, power, psychology and political philosophy, using concepts from Michel Foucault's (1926-1984) repertoire and the trusteeship paradigm. Eido brings Foucault and Abderrahmane together because both deal with the human psyche, the will to power, authority, sovereignty, truth, ethics, and discipline. This chapter problematizes Foucault's concept of the will of the self to knowledge, its desires, sexual desires, and its unveiling of the real authorities, or biopolitics, that influence it, thus unveiling its own authority, liberty, and its limitations. Such unveiling leads to recognition of power dynamics, internal and external, which, in turn, leads to self-empowerment, and to the formation of new authority, through surveillance, and not necessarily through direct oppression. The major point Eido takes from introducing Foucault here is the latter's idea that power/authority originates from below, from the selves themselves, and not necessarily from top-down institutions and external authorities and that oppression, too, permeates and is invisible. That is, the human self, singular or plural, is the source of power and a means of oppression. Here starts the role of the trusteeship apparatuses and concepts Eido borrows to counter Foucault. Abderrahmane does not seek power, or sovereignty (tasayyud) as understood in the secular socio-political sphere, he seeks profound ethical discipline, explained through different concepts and levels of self-enrichment and empowerment. His aim is rather to persistently tame the egoist self and cultivate a moralist one that liberates itself from both internal and external desires. Eido brings in the different distinctions the trusteeship paradigm makes in law (e.g. figh amrì versus fiqh i'timārī), and the different worlds it builds its assumptions on ('älam al-ghayb and 'älam alshahāda). Put differently, when the other world is being recognized, the selfdisciplines itself to meet its ethical requirements, and its abusive sovereignty is theoretically non-existent. Not because there are no complexities that nurture the feeling of power and oppression but because there is a recognition of these complexities, and a recognition that they could be overcome through 
spiritual discipline (tazkiya), and not through mere spirituality. Recognizing another world is a space of liberty, and not of oppression, neither of the self nor of the other or society, politically speaking.

In the fifth chapter "al-Mumārasa al-Siyāsiyya al-Diyāniyya: al-Naqd al-Tazkawī wa-l-Badīl al-I'timān̄̄” (Religious Political Practice: Spiritual Critique and the Trusteeship Alternative) Adil Et-Tahiri synthetically engages with the political philosophy and theology of Abderrahmane. He first summarizes the trusteeship critique of the various schools of Western political philosophy, from early modern thinkers to the contemporary ones, that defend the idea that secular democracy ultimately will replace the divine sovereign with the sovereign man. Even modern democratic regimes and wealthy societies can return to totalitarianism, fascism and colonialism, as has happed in the first part of the twentieth-century in Europe, for one major reason: the lack of profound ethos that governs the sovereign man. The latter can be rational and modern but can turn totalitarian, fascist and colonialist, since secularism as a worldview is merely utilitarian, and does not consider the different other. The same critique is levelled against modern political Islam and Salafism, since they use a religious rhetoric without a genuine absorption of the Islamic ethos for personal spiritual growth (tazkiya) and for public giving and sharing. In brief, modern politics, be it secular or religious, lags behind an ethical worldview that the trusteeship concept of "disturbance politics" (siyāsat al-iz‘ajj) presents. This concept is spiritual in essence, and starts from changing the individual profoundly, before any outer or social change. Abderrahmane is not in favour of revolutions, coup d'états, or rebellions as a means of changing unjust political systems. He defends non-violence as a method of trusteeship. "Disturbance politics" remains ethical, spiritual in the first place, individual-centered, and non-violent when it calls for change. At the end of the chapter, however, Et-Tahiri questions the feasibility of change through such a method when it is rooted in Suf individuality and is radically non-violent. How would social justice come about if the dictator in a political regime, for example, is very violent, tyrannical and suppressive of any call for change, be it violent or nonviolent?

In the sixth chapter, "Qur'anic Values and Modernity in Contemporary Islamic Ethics: Taha Abderrahmane and Fazlur Rahman in Conversation," Ramon Harvey compares Abderrahmane's interpretation of Qur'anic ethics, and how he uses them to strongly critique both Western modern values as well as the classical classification of major values, with the modern hermeneutics of Fazlur Rahman, influenced by Emilio Betti (189o-1968) and Hans-Georg Gadamer (1900-2002), who aims at building on modern values, and enrich them with Qur'anic ethics. Harvey argues that Abderrahmane's ethical theory 
remains abstract, metaethical, while Rahman's builds social ethics that are relevant to practical needs in society. Both scholars agree on the fact that ethics are the major motor for renewal, but their ideas about how this should be done is where they differ. Rahman emphasises the moral impetus for social development, not only for Sufi and individual development. He is historicist in reading the sacred text and its legal prescriptions through the "double movement theory" while Abderrahmane is critical of historicist approaches since they desacralize the sacred, and propose "spiritual modernity" as an outlet. Harvey also refers to the scholars that adopt these two approaches and apply them to different fields and contexts, as a form of contributing to the debate on ethics in Islamic scholarship in the present and future, for what he calls an "ethical modernity."

In the seventh chapter, "The Modern Mysticism of Taha Abderrahmane," Harald Viersen takes the reader to another theme of no less importance and relevance, i.e. Sufism in modern secular times. Viersen problematizes spirituality and Sufism as strongly found in the thought and work of Abderrahmane, and makes them talk to modern theories of spirituality, with a focus on two major figures for comparison, Abdurrahman Badawi (1917-2002), and Adonis (b. 1930), two prominent contemporary Arab thinkers. Badawi is an existentialist philosoper who found in Islamic spirituality and Sufi tradition what to enrich his existentialist stance with, while Adonis is a poet-thinker who reads Sufism from a secular perspective. Unlike these two interpretations of the role of Sufism in change in Arab-Islamic societies, Abderrahmane builds his whole philosophy on what he calls "supported reason" (al-aqlal-mu'ayyad) that goes beyond "abstracted reason" (al-aqlal-mujarrad), which he associates with Western modernity, and "guided reason" (al-aql al-musaddad), which he associates with a kind of semi-Islamic interpretation that is not innovative, critical, and faithful to the ethical core of the tradition. Viersen ends his paper with reflecting on the fact that the modern role Abderrahmane gives to Sufism in the trusteeship paradigm would influence the epistemological and ontological apparatus on which it rests, a note that remains open for future research - and which the other chapters in this volume deal with from various disciplinary perspectives. On the ontological level, for instance, the chapter of Ourya on bioethics and euthanasia relate to the ontological questions of the relevance of being and existence of the individual/patient despite their "paralyzed" physical status. As to the epistemological level, all the other chapters deal with this level, i.e. the nature of knowledge and justification as they relate to particular fields, like politics, dialogue, socio-anthropology, or hermeneutics and the interpretation of texts based on a particular cosmology, the ontology of the Qur'an in this case. 
Part two of the volume comparatively examines how trusteeship ethics could be applied in different disciplines, in the exact as well as in the social sciences. If in the introduction of this volume we gave examples of how modern ArabIslamic scholarship on ethics has remained mostly theoretical, this part shows how the trusteeship paradigm has first theorized itself as an applicable theory of ethics, and second how researchers find its conceptual apparatuses and advances relevant to their various fields of expertise, as in sociology, anthropology, and medical sciences.

To start with the social sciences, in chapter eight, "The Anthropology of Islam in Light of the Trusteeship Paradigm," Amin El-Yousfi engages with the contemporary debates in anthropology and the study of Muslims and Muslim societies, based on a secular understanding of reason, self, body, and virtue. Dissatisfied with the various trends in the field, including the renowned apparatus and concepts developed by Talal Asad (b. 1932) and his student Saba Mahmood (1962-2018), El-Yousfi says that their concepts, i.e. "discursive tradition" and "piety" respecively, remain a product of modern scholars that espouse the secular versus religious worldview, which the Islamic worldview, as philosophically re-introduced in the trusteeship paradigm, does not recognize. Through matching various concepts from the field of anthropology — or rather ethnography at large - and moral philosophy_relying heavily on Alasdair MacIntyre (b. 1929) - with concepts from the trusteeship paradigm and its conception of the relation between reason and action, typology of reasons, and typologies of expressing ethical affiliation to tradition, El-Yousfi proposes that trusteeship is a more adequate intellectual bank from which to borrow concepts, thus methodology, in the study of Muslim ethics, agency, piety, and connection to tradition.

Connected to this debate in anthropology is also Mohamed Amine Brahimi's chapter nine "The Trusteeship Paradigm in the Social Sciences: Moral Agency as an Islamic Ethical Turn." Here, the author reviews the so-called "ethical turn" as initiated by scholars like Elizabeth Anscombe (1919-2001), Philippa Foot (1920-2010), Bernard Williams (1929-2003), and especially Alasdair MacIntyre in moral philosophy, and Talal Asad and his disciples in anthropology. Unlike El-Yousfi, in the earlier chapter, who proposes that the trusteeship paradigm could be an alternative apparatus to the study of Muslims' agency and ethics, in replacement of secular versus religious Western dichotomous thought, Brahimi proposes a dialogue of concepts, though he also thinks that the trusteeship is a more fitting and promising apparatus that provides answers to the scholarly debates around the "ethical turn" and "virtue ethics" in the social sciences. Put differently, Brahimi distinguishes between the Eurocentric approach that explains religiosity through private faith and the "ethical turn" that takes into account rituals, bodily expressions, and the contexts or spaces in which 
this faith is expressed, and through which a moral character is formed. Brahimi uses Abderrahmane's critique of modernity, and the principles of trusteeship as more adequate explanations of Islamic subjectivity and agency, away from the secular versus religious, rational versus revelational outlook.

Mohamed Ourya takes us to medical ethics in chapter ten "al-I'timāniyya Nazariyya li-Hāl al-Mu'ḍilāt al-Akhlāqiyya al-Tlmiyya: al-Bỉa wa-l-Mawt alRahīm Namūdhajan" (Taha Abderrahmane's Trusteeship's Response to Ethical Issues: The Environment and Euthanasia in Focus). The author examines major points related to Abderrahmane's critique of Western modernity, and his ethical theory as it engages with environmental ethics, and biomedical ethics, euthanasia in particular, with a focus on utilitarianist and principalist theories. He also compares the European critical thought of over technologization, examplified by the thought of Hans Jonas (1903-1993), Karl-Otto Apel (1922-2017), and Jürgen Habermas (b. 1929). More space is given to Abderrahmane's engagement with especially the environmentalist thought of Hans Jonas and his theory of responsibility, which the former finds incomplete since it does not use the metaphysical reward and punishment apparatus in sensibilizing humanity of the risks facing nature and environment. Ourya uses some concepts of the trusteeship paradigm in responding to what Abderrahmane considers to be lacunae in Western secular ethical theories. These concepts, developed into theoretical principles, are as follows: mercy (rahma), trusteeship or guandianship (amāna), and requisition ( $\left.\bar{\imath} d \bar{a}^{c}\right)$. Overall, Ourya argues that although Abderrahmane appears to be very dismissive of Western modernity, his Islamic theory of ethics as it relates to these two research fields remains open to "Western" ethical theories, like Kantian ethics and to classical Greek virtue ethics. While the argumentation and details may differ, there are plenty of similarities and correlations.

In chapter eleven, "al-Taqwīm al-Akhlāqī lil-'Tlmāniyya bayna Ṭāha 'Abd al-Raḥmān wa-Ṭalāl Asad: al-Usra al-Ḥadītha Namūdhajan” (Secularism Criticised from an Ethics Perspective in the Work of Taha Abderrahmane and Talal Asad:The Modern Family in Focus), Abdelmounim Choqairi, like El-Yousfi and Brahimi in the previous chapters, applies a number of trusteeship conceptual apparatuses to the case of the modern family and how it has evolved in the modern, secular-liberal context. First, Choqairi presents the similarities and differences in the approaches of Talal Asad and Taha Abderrahmane towards the secular, before he chooses to centralize their shared use of the secular, i.e. the secular as an epistemological worldview in opposition to, or at least in competition with, the religious epistemical worldview. Afterwards, he makes the anthropological critique of the secular and its effect on the family in the work of Asad speak to the theoretical advances of Abderrahmane on the same 
theme, family. While Asad explains that the rationalization of ethics through modern secular laws ended the positive mediation capacities of religion and religious authorities in society for the maintenance of family coherence and its rationale, Abderrahmane proposes a return to the religious ethos to reclaim the family per se, since without ethics in the nucleus of society-i.e. family-there could be no ethics at the social and societal level. Family is the mirror of society and its situation. With the globalization of the market, and the privatization of ethics, family too has been privatized and in such a process what used to be a public matter-i.e. the family - is no longer so. The family has fallen prey to the epistemology of the secular and to the secularization process, driven by the global utilitarian market. The three principles of magnanimity, happiness and obligation, that are supposed to govern family ethics, have given way to rationalized, privatized and market-oriented ethics defended by global markets and international institutions for this purpose. Choqairi presents various principles of the trusteeship paradigm as a correction means to the loss of family harmony and ethics to the secularized market-oriented ethics, but wonders at the end if these principles, rooted in spirituality, will be able to face this growing challenge successfully.

Hicham El Makki introduces us to the field of the mass media and communication and how the trusteeship paradigm engages with it in chapter twelve, "al-I'timāniyya fī Majāl al-I'lām wa-l-Ittiṣāl: al-Imkānāt wa-l-Hudūd" (The Trusteeship Thought Applied to Media and Communication: Scope and Limitations). Like Ourya in his chapter, El Makki first shows how Abderrahmane grapples with the major literature in the field of the media, and introduces trusteeship as a correcting ethical outlet for the current and future crises of this unprecedented age of technology and communication. In doing so El Makki then reminds us of Abderrahmane's proposal of the "trusteeship contract" instead of the common "social contract." This proposal is based on three major trusteeship guidelines: philosophic, juristic, and educational. The "trusteeship educator", or "al-faqīh al-itimānī", plays a major role in guiding individuals and society for the achievement of ethical awareness in treading the over-technologized and mediatized modern world. Finally, the author outlines a number of limitations as well as potential energy of the trusteeship paradigm in the field of the mass media. For example, he says that Abderrahmane, while showing profound familiarity with major schools and texts on the media theories, he still misses engaging with some, especially the ones widespread in the Anglo-Saxon world and literature. El Makki also states that while the logical argumentation of Abderrahmane may be too abstract and hard to penetrate and engage with, his trusteeship paradigm as applied to the world of the media is innovative and can open up new spaces of creativity in the field. 
Assia Chekireb contributes the closing chapter, thirteen, "al-Hiwār bayna al-I’timāniyya wa-l-Akhlāq al-Ālamiyya: Muqāaba Taḥlīliyya Muqārana" (Dialogue between The Trusteeship Theory and Global Ethics: A Comparative Approach) in comparative studies in the fields of religious dialogue, pluralism, and global ethics. Chekireb brings Hans Küng (b. 1928) and Taha Abderrahmane to the same table for discussion. After presenting their similar major views on dialogue and shared humanity among religious, philosophical and moral worldviews, and their critique of the limitations of modern human reason and the Enlightenment project, she goes on to trace out the differences between the two philosophers. She spends some time recalling the internationally acclaimed work of Küng on "global ethics" thesis and manifesto, and the major ideas he defends here, i.e. the defence of possible shared ethics, based on the "golden rule" found in world religions, for the formation of world peace, solidarity, tolerance and social justice. According to Chekireb, Küng does not see that religion or religions alone, let alone one religion, can solve major human problems. On the other hand, in introducing the trusteeship paradigm of Abderrahmane, she introduces critique of Küng's thesis. Abderrahmane is critical of Küng's thesis of "global ethics" for one major reason: the latter divests these ethics of their religious origins, and, subsequently, from their rootedness in practice. Global ethics remain abstract unless tested in practice, and they cannot be tested in practice since they require genuine ethos that is truly practiced, hence the need for religion, especially divinely-revealed religion for genuine global ethics, according to Abderrahmane. Put differently, the trusteeship paradigm proposes practical spiritual concepts for ethical renewal, or else the global ethics thesis remains a rhetoric, a discourse void of substance, like abstract ethics and abstract reason. In her conclusion Chekireb also wonders, like Choqairi in the previous chapter, whether the trusteeship concepts could be effective in such a challenging, globalized and gradually secularized world.

These interdisciplinary excavations into the scope and limitations of the trusteeship paradigm leave us with three major notes, with which we conclude. First, the paradigm is a remarkable field of intellectual energy in the Arab-Islamic domain, and we, the editors, are happy to have managed to bring together a number of scholars and researchers from around the world to discuss it from different angles. Second, trusteeship critique engages with Arab-Islamic classical and modern scholarship, and does so too with Graeco-Euro-American scholarship. Certainly, it is ambitious and confident, maybe too confident, in critiquing all of it. The merit of this volume has been to show such claim of innovative critique and its limitations. Being the first volume that opens such a door in comparative scholarship, we hope to see more of the kind to be produced, and we do not doubt that such a project will meet more critical eyes 
in the future. We finally note that such eyes should pay attention to at least two major fields that this volume has not covered in approaching the trusteeship paradigm, i.e. logic, and the philosophy of language. These two fields of research would give more insight into why and how Taha Abderrahmane, a staunch defender of philosophy, reason as well as divinely inspired ethics, is very critical of the current phase of modernity.

\section{References}

'Abd al-Rahmān, Ṭāha. 1994. Tajdìd al-Manhaj fì Taqwìm al-Turāth [Renewing the Method of Assessing the Tradition]. Casablanca and Beirut: al-Markaz al-Thaqāfi al-'Arabì.

'Abd al-Rāziq, Mușțafa, [1944] 2011. Tamhīd li-Tārīkh al-Falsafa al-Islāmiyya [Introduction to the History of Islamic Philosophy]. Intr. Muhammad Hilmī 'Abd al-Wahhāb. Cairo and Beirut: Dār al-Kitāb al-Miṣrī, and Dār al-Kitāb al-Lubnān̄̄.

Adamson, Peter. 2015. Philosophy in the Islamic World: A Very Short Introduction. Oxford: Oxford University Press.

Adamson, Peter and Richard C. Taylor. Eds. 2005. The Cambridge Companion to Arabic Philosophy. Cambridge: Cambridge University Press.

Al-Attar, Mariam. 2010. Islamic Ethics: Divine Command Theory in Arabo-Islamic Thought. New York and London: Routledge.

Al-'Aqqād, 'Abbās Maḥmūd. [1947] 2013. Al-Falsafa al-Qurāaniyya [Qư'anic Philosophy]. Cairo: Hindāwī.

Amīn, Ahmad. [1929] 2011. Kitäb al-Akhlāq [The Book of Ethics]. Cairo: Hindāwī. Amīn, Aḥmad. [1945] 2013. Zuhr al-islām [The Rise of Islam]. Cairo: Hindāwī.

Arkūn, Muhammad. 199o. Al-Islām, al-Siyāsa, wa-l-Akhläq [Islam, Politics, and Ethics]. Trans. Hāshim Ṣālih. Paris and Beirut: Unesco and Markaz al-Inmā̄ al-Qawmī.

Arkoun, Mohamed. 2007. Islam: to Reform or to Subvert? London: Saqi Books.

Arkoun, Mohammed, trans. [1969] 2010. Miskawayh. Traité d'étique (Tahdīib al-Ahlāq wa-Tathīir al-A'rāq). Paris, Vrin.

'Ațiyya, Ahmad 'Abd al-Halīm. 199o. Al-Akhlāq fì al-Fikr al-Arabī al-Mu'āṣir [Ethics in Contemporary Arab Thought]. Cairo: Dār al-Thaqāfa lil-Nashr wa-l-Tawzī'.

Bachir Diagne, Souleymane. 2018. Open to Reason: Muslim Philosophers in Conversation with the Western Tradition. New York: Columbia University Press.

Badawī, 'Abd al-Rahmān. 1953. Hal Yumkin Qiyām Akhlāq Quyūdiyya? [Are Existential Ethics Possible?]. Cairo: Maktabat al-Nahḍa al-Mișriyya.

Al-Bishrī, Țāriq. 2004. "Hawla al-'Aql al-Akhlāqī al-Arabī: Naqd li-Naqd al-Jābrī.” In Kamāl 'Abd al-Lațîf, ed. Al-Turāth wa-l-Nahḍa: Qirä̉āt fì A'māl Muhammad Ābid alJābrī. [On Arab Ethical Reason: Critique of the Critique of al-Jabri. In Tradition and 
Renaissance: Readings in the Works of Mohammed Abed Al-Jabri]. Beirut: Markaz Dirāsāt al-Waḥda al-'Arabiyya: 97-118.

Booth, Anthony Robert. 2017. Analytic Islamic Philosophy. London: Palgrave Macmillan. Campanini, Massimo. 2008. An Introduction to Islamic Philosophy. Edinburgh: Edinburgh University Press.

Corbin, Henry. [1962] 2001. History of Islamic Philosophy. Trans. Liadain Sherrard and Philip Sherrard. London and New York: Kegan Paul International and the Institute of Ismaili Studies.

Daiber, Hans. 1999. Bibliography of Islamic Philosophy. 2 Vols. Leiden: Brill.

Daiber, Hans. 2007. Bibliography of Islamic Philosophy: Supplement. Leiden: Brill.

De Galarza, Comte. 1920. Muhạậarāt al-Falsafa al-Āmma wa-Tārīkhuhā fì al-Jāmi'a al-Mișriyya [Lectures on General Philosophy and Its History at the Egyptian University]. Intr. and ed. Aḥmad 'Abd al-Ḥalīm 'Ațiyya, 3-18. N.p. Maktabat al-Muhtadīn al-Islāmiyya li-Muqāranat al-Adyān.

Darrāz, Muḥammad 'A. [1947] 1973. Dustūr al-Akhlāq fi al-Qur'ān. Trans. 'Abd al-Ṣābūr Shāhīn. Rev. Muhammad Badawī. Cairo: Mu’assasat al-Risāla wa-Dār al-Buhūth al'Ilmiyya.

Draz, Muhammad A. 20o8. The Moral World of the Qur'an. Trans. Danielle Robinson and Rebecca Masterton. London and New York: I.B. Tauris.

El-Rouayheb, Khaled and Sabine Schmidtke, eds. 2017. The Oxford Handbook of Islamic Philosophy. New York: Oxford University Press.

Eyadat, Zaid, Francesca M. Corrao, Mohammed Hashas, eds. 2018. Islam, State, and Modernity: Mohammed Abed al-Jabri and the Future of the Arab World. New York: Palgrave MacMillan.

Fakhrī, Majīd. 1978. Al-Fikr al-Akhlāqī al-Arabī. Vol. 1: al-Fuqahä’ wa-l-Mutakallimūn [Arab Ethical Thought: Vol. 1: Jurists and Theologians]. Beirut: al-Ahalliyya lil-Nashr wa-l-Tawzī'.

Fakhrī, Majīd. [1978] 1986. Al-Fikr al-Akhlāqī al-'Arabī [Arab Ethical Thought]. 2nd ed. Amman: Dār al-Ahalliyya lil-Nashr.

Fakhry, Majid. 1991. Ethical Theories in Islam. Brill: Leiden and New York.

Fakhry, Majid. [1970] 2004. A History of Islamic Philosohy. 3rd ed. New York: Columbia University Press.

Ghaly, Mohammed. 2017. "The Journal of Islamic Ethics: A Pressing Demand and a Promising Field." Journal of Islamic Ethics 1 (1-2): 1-5.

Hallaq, Wael B. 2013. The Impossible State: Islam, Politics, and Modernity's Moral Predicament. New York: Columbia University Press.

Hallaq, Wael B. 2019. Reforming Modernity: Ethics and the New Human in the Philosophy of Abdurrahman Taha. New York: Columbia University Press.

Hashas, Mohammed. 2015. "Taha Abderrahmane's Trusteeship Paradigm: Spiritual Modernity and the Islamic Contribution to the Formation of a Renewed Universal Civilization of Ethos." Oriente Moderno 95 (1-2): 67-105. 
Hashas, Mohammed. 2019. The Idea of European Islam: Religion, Ethics, Politics and Perpetual Modernity. London: Routledge.

Hourani, George F. 1985. Reason and Tradition in Islamic Ethics. Cambridge and New York: Cambridge Univeristy Press.

Izutsu, Toshihiko. [1966] 2002. Ethico-religious concepts in the Qur'an. Montreal and London: McG-Queen's University Press.

Al-Jābrī, Muhammad 'Ābid. 1991. Al-Turāth wa-l-Hadātha [Tradition and Modernity]. Beirut: Markaz Dirāsāt al-Waḥda al-'Arabiyya.

Al-Jābrī, Muḥammad 'Ābid. 20o1. Naqdal-Aqlal-Arabī:al-Aqulal-Akhlāqīal-'Arabī. [The Critique Of Arab Reason: The Arab Ethical Reason]. Vol. 4/4. Beirut: The Center for Arab Unity Studies.

Jackson, Roy. 2014. What Is Islamic Philosophy? Oxon and New York: Routledge.

Khalidi, Muhammad Ali, ed. Medieval Islamic Philosophical Writings. Cambridge: Cambridge University Press, 2005 .

Al-Khațīb, Mu'tazz. 2017. "Āyāt al-Akhlāq: Su’āl al-Akhlāq 'Inda al-Mufassirīn" [The Verses of Ethics: The Question of Ethics in the Work of Exegetes]. Journal of Islamic Ethics 1 (1-2): 84-121.

Al-Khatib, Mutaz. 2019. "The Emerging Field of Ethics in the Context of Modern Egypt.” In Bettina Gräf, et al., eds. Ways of Knowing Muslim Cultures and Societies: Studies in Honour of Gudrun Krämer. Leiden and Boston: Brill: 157-180.

McGinnis, Jon and David C. Reisman. Trans and Intr. 2007. Classical Arabic Philosophy: An Anthology of Sources. Indianapolis, IN: Hackett Publishing Company.

Leaman, Oliver. [1985] 2004. An Introduction to Classical Islamic Philosophy. Cambridge: Cambridge University Press.

Leaman, Oliver. 2016. The Qur'an: A Philosophical Guide. London and New York: Bloomsbudy Academic.

Leaman, Oliver. 2019. Islam and Morality: A Philosophical Introduction. London and New York: Bloomsbury Academic.

Luṭ̂ī al-Sayyid, Aḥmad, trans. [1919] 1934. Ilm al-Akhlāq ilā Nīqūmākhus [Nichomachean Ethics]. 2 Vols. Cairo: Dār al-Kutub al-Mișriyya.

Madkūr, Ibrāhīm. [1947] 2015. Fì al-Falsafa al-Islāmiyya: Manhajun wa-Tațbīquh [On Islamic Philosophy: A Method and Its Application]. 2 Vols. Intr. Munā Aḥmad Ab̄̄ Zayd. Cairo and Alexandria: Dār al-Kitāb al-Mișrī and Maktabat al-Iskandariyya.

Maḥmūd Șubḥī, Aḥmad. [1969] 2006. Al-Falsafa al-Akhlāqiyya fì al-Fikr al-Islāmī: al'Aqliyyūn wa-l-Dhawqiyyūn aw al-Nazar wa-l-Amal [Philosophy of Ethics in Islamic Thought: The Rationalists and the Sufis, or Sight and Practice]. 2nd ed. Cairo: Dār al-Ma'ārif.

Mūsā, Muḥammad Yūsuf. [1940] 1953. Tārīkh al-Akhlāq [History of Ethics]. 3rd ed. n.p. Dār al-Mațābi ' bi-Mișr.

Mūsā, Muḥammad Yūsuf. 1958. Al-Qur'ān wa-l-Falsafa [The Qur’an and Philosophy]. Cairo and Beirut: Dār al-Kitāb al-Miṣrī, and Dār al-Kitāb al-Lubnānī. 
Mūsā, Muḥammad Yūsuf. 2018. Mabāḥith fí Falsafat al-Akhlāq [Issues in Moral Philosophy]. Cairo: Hindāwī.

Al-Nashshār, 'Alī Sāmī. [1966] 1977. Nash’at al-Fikr al-Falsafífi al-Islām [The Development of Philosophical Thought in Islam]. Vol. 1/3. 9th ed. Cairo: Dār al-Macārif.

Al-Nashshār, 'Alī Sāmī. [1968] 1977. Nash’at al-Fikr al-Falsafí fì al-Islām [The Development of Philosophical Thought in Islam]. Vol. 2/3. 8th ed. Cairo: Dār al-Mac̄arif.

Al-Nashshār, 'Alī Sāmī. [1969] 1988. Nash’at al-Fikr al-Falsafí fì al-Islām [The Develop-

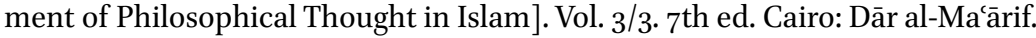

Nasr, Seyyed Hossein. 20o6. Islamic Philosophy from its Origin to the Present: Philosophy in the Land of Prophecy. New York: State University of New York Press.

Qābīl, 'Abd al-Hayy. 1984. Al-Madhāhib al-Akhlāqiyya fì al-Islām: al-Wājib wa-l-Sac̄à [Schools of Ethics in Islam: Obligation and Happiness]. Cairo: Dar al-Thaqāfa lilNashr wa-l-Tawzīc.

Al-Qaraḍāwī, Yūsuf. 1995. Al-Qiyam wa-l-Akhlāqfìal-Iqtșād al-Islāmī [Values and Ethics in Islamic Economics]. Cairo: Maktabat Wahba.

Al-Qaraḍāwī, Yūsuf. 2017. Akhlāq al-Islām [The Ethics of Islam]. Beirut: Dār al-Mashriq.

Rahbar, Daud. 196o. God of Justice: A Study in the Ethical Doctrine of the Qur'an. Leiden: Brill.

Rahman, Fazlur. 1982. Islam and Modernity: Transformation of an Intellectual Tradition. Chicago: University of Chicago Press.

Rashwānī, Sāmir. 2017. "Al-Dars al-Akhlāqī lil-Qurāā: Qirāa fĩ Ba‘ḍ al-Muqārabāt alHadītha” [The Qur'an's Lesson on Ethics: Reviewing Some Modern Approaches]. Journal of Islamic Ethics 1 (1-2): 158-194.

Reid, Donald Malcolm. 1987. "Cairo University and the Orientalists." International Journal of Middle East Studies 19 (1): 51-75.

Șalībā, Jamīl. 1989. Tārīkh al-Falsafa al-Arabiyya [History of Arabic Philosophy]. Beirut: Al-Sharika al-Ālamiyya lil-Kitāb, Dār al-Kitāb al-'Ilmī, al-Dār al-Ifrīqiyya al-'Arabiyya.

Sayoo, Amyn B. 2004. Muslim Ethics:Emerging Vistas. London and New York: I.B. Tauris, in association with the Institute of Ismaili Studies.

Sayoo, Amyn B., ed. 2010. A Companion to Muslim Ethics. London and New York: I.B. Tauris, in association with the Institute of Ismaili Studies.

Al-Shamma, Salih Hadi. 1959. The Ethical System Underlying the Qur'an: A Study of Certain Negative and Positive Notions. PhD dissertation, University of Edinburgh.

Al-Ṭawil, Tawfīq. [1952] 1958. Usus al-Falsafa [The Roots of Philosophy]. 3rd ed. Cairo: Maktabat al-Nahḍa al-Mișriyya.

Taylor Richard C. and Luis Xavier Lòpez-Farjeat, eds. 2016. The Routledge Companion to Islamic Philosophy. Routledge: London and New York.

Tymieniecka, Anna-Teresa and Nazif Muhtaroglu, eds. 2010. Classical Issues in Islamic Philosophy and Theology Today. Dordrecht and London: Springer. 
Watt, Montgomery. [1962] 1985. Islamic Philosophy and Theology: An Extended Survey. Edinburgh: Edinburgh University Press.

Wāṣif Bik, Amīn. 1921. Ușūl al-Falsafa [The Fundamentals of Philosophy]. 1st ed. 5 Vols. Cairo: Maṭbacat al-Ma'ārif.

Zureiq, Costantin, ed., annot. 1966. Ibn Miskawayh: Tahdhīb al-Akhlāq. Beirut: The American University. 